\section{Zdzisław Żywica}

Uniwersytet Warmińsko-Mazurski w Olsztynie zjzywica@poczta.onet.pl

DOI: http://dx.doi.org/10.12775/BPTh.2016.020

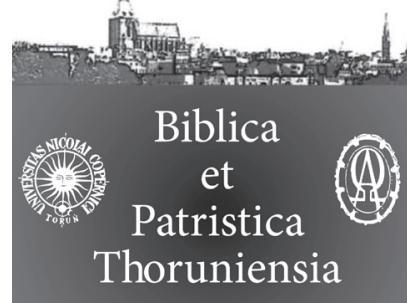

9 (2016) 2: 169-185

ISSN (print) 1689-5150

ISSN (online) 2450-7059

\title{
Pawłowe rozumienie syneidēsis w Rz 2,9-16
}

\section{Paul's understanding of syneidēsis in Rom 2:9-16}

\begin{abstract}
Streszczenie. Analiza egzegetyczna jednostki 2,9-16 oraz jej kontekstu (sekcji 1,18-4,25) pozwala stwierdzić, że Paweł chce tu nadać greckiemu pojęciu sumienie podobny sens i funkcję jaką pełni serce w tradycji biblijnej i judaistycznej. Wychodzi od wykazania, że wszyscy Żydzi i Grecy zgrzeszyli i dlatego znaleźli się w identycznym położeniu względem sprawiedliwości Bożej, pomimo posiadanego przez jednych Prawa objawionego a przez drugich Prawa naturalnego. Skoro Prawo okazało się nieskuteczne na drodze zbawienia ludzkości to oznacza, że straciło ono skuteczność zbawczą, czego dowodem jest nowa inicjatywa zbawcza Boga zrealizowana w dziele usprawiedliwienia wszystkich za darmo, mocą krwi Jezusa Chrystusa (3,25a). Każdy człowiek może dostąpić tejże łaski przez wyznanie wiary w Chrystusa. Jednak żeby dostąpić daru pokoju oraz uczestnictwa w chwale i czci Boga w wieczności wyznawcy Jezusa muszą konsekwentnie formować swoje serca i sumienia nowym Prawem, to znaczy muszą je obrzezać Ewangelią Chrystusa Syna Bożego, która stała się jedyną moca Boża wiodąca ku zbawieniu $(1,16)$. Dowodem zaś na tak odnowiony przez Boga porządek zbawczy jest zapowiedziany sąd nad całą ludzkością w dniu ostatecznym, którego dokona On przez Jezusa Chrystusa na podstawie Ewangelii.
\end{abstract}

Abstract. Exegetical analysis of unit 2:9-16 and its context (see 1:18-4:25) shows that Paul wants to give the Greek notion of "conscience" a similar meaning and function as "heart" in the biblical and Judaism tradition. He assumes that all the Jews and Greeks have sinned and therefore find themselves in the same position relative to the righteousness of God, even though possessed by ones the Law revealed while by others the natural rights. Since the Law has proved ineffective in the way of salvation of mankind that means it also lost its salvific efficacy, as evidenced by the new initiative of God's saving work carried out in the justification free for all, by virtue of the blood of Jesus Christ (3.25). Each person can be granted with this grace by profession of faith in Christ. However, to obtain the gift of peace, participate in the glory and praise of God in eternity, followers of Jesus must consistently educate their heart and conscience of the new law, that is, they must be circumcised by Gospel of Christ, the Son of God, which became the only power of God leading to salvation (1.16). The proof of such restored by 
God's order of salvation is the announced judgment on the whole of humanity on the last day, which he will complete by Jesus Christ based on the Gospel.

Słowa klucze: serce; sumienie; syneidēsis; obrzezanie; Prawo; grzech; usprawiedliwienie; Jezus; Ewangelia.

Keywords: hearth; conscience; syneidēsis; circumcise; Law; sin; justification; Jesus; Gospel.

$\mathrm{W}$ Liście do Rzymian Paweł stosuje trzykrotnie termin syneidēsis (sumienie): w pierwszej i trzeciej sekcji Probatio $(2,15 ; 9,1)$ oraz w części $\mathrm{Na}$ pomnień $(13,5)^{1}$. Po raz pierwszy czyni to w centralnej części sekcji 1,18-4,25², w wypowiedzi którą Apostoł redaguje jako samodzielną jednostkę argumentacyjną 2,9-16 3 . Poprzedza ona jednostkę w której Paweł dokonuje zmiany jakościowej w charakterystyce trzeciej grupy ludzi (2,17-29), w porównaniu do jednostek ją poprzedzających, gdzie opisuje on dwie inne negatywne grupy (1,19-32; 2,1-8). Tak zrealizowana przez niego strategia kompozycyjno-retoryczna pierwszej sekcji Listu każe postawić kilka pytań. Najpierw o to, jaką funkcję przypisuje tej jednostce w jej kontekście retorycznym sekcji 1,18-4,25? Następnie, czy zastosowany tu termin syneidēsis odnosi on tylko do Żydów czy też jedynie do Greków, a może do jednych i drugich? Dalej, jak rozumie to pojęcie w tym konkretnym kontekście, jaki nadaje mu sens oraz jaką przypisuje mu funkcję i znaczenie w ocenie własnych działań przez człowieka, jak również w jego relacji do Boga, Jego sądu i wieczności eschatologicznej?

\section{Kontekst: usprawiedliwienie w Jezusie $(1,18-4,25)$}

Głównym tematem całej sekcji jest problem usprawiedliwienia. Paweł wykazuje w niej, że może się ono dokonać jedynie przez wiarę w Jezusa Chrystusa, że jest jednakowe dla wszystkich i powinno zrealizować się w taki sam sposób

1 Punktem wyjścia dla prowadzonych analiz egzegetycznych będzie kompozycja Listu zaproponowana przez J.-N. Aletti (List do Rzymian, s. 1411n). Wygląda następująco: Praescriptum (1,1-7); Exordium (1,8-17) kończące się Propositio do całego Listu (1,16-17); Probatio składające się z trzech sekcji tematycznych: A) Żyda i Greka usprawiedliwia jedynie wiara (1,18-4,25), B) Nowe życie i nadzieja ochrzczonych (5-8), C) Izrael i poganie: przyszłość Izraela (9-11); Napomnienia (12,1-15,13); Peroratio (15,14-21); Informacje i pozdrowienia końcowe (15,22-33 + 16,1-27), z Postscriptum w 15,33.

2 Sekcja 1,18-4,25 zbudowana jest $\mathrm{z}$ dwóch podsekcji: 1,18-3,20 i 3,21-4,25.

3 Por. J.-N. Aletti, List do Rzymian, s. 1418n. 
zarówno dla Żydów jak i Greków, ponieważ jedni i drudzy znaleźli się w identycznym położeniu wobec sprawiedliwości Bożej, Jego sądu i odpłaty. W podsekcji pierwszej $(1,18-3,20)$ zastanawia się on nad formami Bożej odpłaty w świetle judaizmu. W drugiej natomiast $(3,21-4,25)$ patrzy na to zagadnienie przez pryzmat wiary w Jezusa i ogłasza nową naukę o usprawiedliwieniu dokonującym się odtąd tylko przez wiarę w Jezusa Chrystusa Syna Bożego niezależnie od uczynków wymaganych przez Prawo Mojżeszowe. Nie powinien zatem dziwić fakt, że przedstawioną tu argumentację rozpoczyna od doskonale znanej mu biblijnej i judaistycznej idei o karzącej sprawiedliwości Bożej, której oczekiwali wszyscy pobożni doświadczający prześladowań i wszelkiego rodzaju niesprawiedliwości. To właśnie im Bóg obiecał wybawienie, karę zaś złym, odpłacając każdemu sprawiedliwie według dokonanych uczynków ${ }^{4}$.

Podsekcja 1,18-3,20 zbudowana jest według ówczesnego wzorca kompozycyjnego ${ }^{5}$. Jej adresatów Paweł nie dzieli według znanego mu prostego judaistycznego klucza na pobożnych i dobrych Żydów oraz bezbożnych i złych Greków (Pogan). Stosowane tu bowiem ogólne określenia, takie jak: „ci ludzie, którzy ...", mogą odnosić się zarówno do jednych jak i do drugich. Podobnie też, gdy stosuje słowo pas (wszystko, wszelka, wszelaka), to bardziej opisuje nim same działania niż osoby działające $(1,18.29)$. Dlatego też, gdy mówi o objawiającym się gniewie Bożym, to nie odnosi go bezpośrednio do grup etniczno-religijnych (Żydów i Greków), lecz do wszelkiej niesprawiedliwości popełnianej przez ludzi występujących przeciwko prawdzie. Ci zaś mogą być zarówno Żydami jak i Grekami $(1,29-31 ; 2,1-5)$. Apostoł nie podaje tu żadnych wskazówek umożliwiających określenie ich liczby i status religijny. Bardzo istotne jest jednak, że przy ich ocenie kieruje się kryteriami moralnymi, osądza ich postawy, zachowania i działania. W pierwszej kolejności wymienia i charakteryzuje dwie grupy takich ludzi. Najpierw pisze o tych wszystkich, którzy czynią zło i akceptują takie działanie u siebie i u innych $(1,19-32)$. Następnie opisuje grupę tych, którzy krytykują i osądzają tych z pierwszej grupy, sami jednak dopuszczają się podobnej niesprawiedliwości $(2,1-8)$. Co do osądu obu grup Apostoł nie pozostawia żadnych wątpliwości, że jednych i drugich dosięgnie sąd i kara Boża $(2,9-11)^{6}$. Nagrodę zaś otrzymają ci, którzy postępują sprawiedliwie, zarówno

4 Por. ibidem, s. 1415 n.

5 Propositio-Probatio-Peroratio: Propositio (1,18); Probatio (1,19-3,18); Peroratio (3,19-20). Por. J.-N. Aletti, List do Rzymian, s. 1416.

6 Apostoł wyraźnie zaznacza, że nie wszyscy ludzie, lecz wszyscy ludzie czyniący zło, bez żadnego wyjątku, poniosą sprawiedliwą karę. 
spośród Żydów jak i Greków $(2,14-15)^{7}$. Od 2,17 Paweł przechodzi do charakterystyki trzeciej, również negatywnej, grupy ludzi. Stanowią ją Żydzi głoszący dobro, ale dopuszczający się zła (2,17-24). Apostoł i tym razem nie określa ich liczby. Mając jednak na uwadze fakt, że unika tu stosowania słowa wszyscy (pas), to również i tym razem ma na myśli część Żydów ${ }^{8}$. W przeciwieństwie do charakterystyki dwóch pierwszych grup, w opisie tej grupy dokonuje zmiany jakościowej. W tym przypadku dotyka bowiem sfery ich świadomości. Postępuje tak, żeby wykazać ich odpowiedzialność za to co czynią, gdyż wiedzą jak osądza takie czyny Prawo dane im przez Boga. Wykazują się bowiem poznaniem istoty Prawa oraz roli jaką powinno odgrywać w ich życiu. Zdają sobie sprawę z tego, że jest ono objawieniem woli Bożej normatywnie ich obowiązującej. Potwierdzają to swym postępowaniem, bowiem to właśnie z tej racji chlubią się nim i głoszą je innym jako objawioną wolę Bożą. Niestety, sami postępują wbrew niej, dopuszczając się tym samym niesprawiedliwości przed jego Dawcą. Takie zaś postępowanie jest znacznie surowiej oceniane przez Boga niż poprzednie (krytyka zła oraz jednoczesne czynienie go) i tym samym pociąga za sobą znacznie większą winę i związane z nią jeszcze głębsze pohańbienie9.

W rozdziale trzecim Paweł jeszcze wyraźniej eksponuje zarówno zmianę ilościową jak i jakościową w ocenie sytuacji grzesznika wobec Bożego sądu i odpłaty. Nie chodzi tu już tylko o tych grzesznych z trzech wcześniej wymienionych grup, lecz o „każdego” człowieka bez wyjątku, każdego Greka i każdego Żyda, nawet tego pobożnego, o którym wspomina w kontekście charakterystyki ludzi dopuszczających się niesprawiedliwości $(3,4.9 .12 .19)$. Koronnym dowodem, absolutnie wiarygodnym i normatywnym, wskazującym na taki właśnie stan całej ludzkości jest Pismo - słowo samego Boga ${ }^{10}$. Sprawiedliwy Bóg nie wylewa jednak swego gniewu na pogrążoną w zepsuciu moralnym ludzkość i nie potępia jej dokonując nad nią sądu. Wręcz przeciwnie, dokonuje czegoś nie tylko dotąd nieoczekiwanego, ale też i będącego całkowitym przeciwieństwem oczekiwanego dotychczas sądu i kary. Zamiast tych sprawiedliwych aktów Bóg dokonuje dzieła usprawiedliwienia (dikaioumenoi/dikaiosynē) wszystkich „za darmo, z Jego łaski, przez odkupienie, które jest w Chrystusie Jezusie” $(3,24)$. Nadto postanowił jeszcze, że każdy człowiek może dostąpić łaski uspra-

7 Apostoł zakłada istnienie grupy ludzi dobrych, którzy będą wynagrodzeni przez Boga, ponieważ tego wymaga Jego sprawiedliwość.

8 Zakłada zatem istnienie grupy pobożnych Żydów wiernie przestrzegających Prawo.

9 Por. J.-N. Aletti, List do Rzymian, s. 1416n.

10 Por. Rz 3,10-18; Ps 14[13],1nn; 5,10; 140[139],4; 10[9],7; Iz 59,7n; Ps 36[35],2. Paweł nie może odwołać się tu do osobistego doświadczenia, ponieważ jego argumenty nie zostałyby przyjęte przez pobożnych Żydów. 
wiedliwienia przez wiarę w Jezusa Chrystusa, „Jego to bowiem ustanowił Bóg narzędziem przebłagania przez wiarę mocą Jego krwi” (3,25a). Dla Pawła jest więc czymś oczywistym, że to wyłącznie w Jezusie, a nie jak dotychczas przez uczynki Prawa, Boża łaskawa sprawiedliwość (usprawiedliwienie) stała się dostępna dla każdego człowieka. Dla całej ludzkości, bez żadnego wyjątku ani przywileju, w taki sam sposób dla każdego Żyda i każdego Greka (3,21-23), bowiem - jak argumentuje - każdy „człowiek osiąga usprawiedliwienie przez wiarę, niezależnie od pełnienia nakazów Prawa” $(3,28)$. Dokonuje się to na podobieństwo tego co wydarzyło się w życiu Abrahama, gdy ten wykazał się wobec Boga wiarą, a On poczytał mu tę postawę za sprawiedliwość $(4,1-25)$, bowiem - jak dowodzi Apostoł - „jeden jest tylko Bóg, który usprawiedliwia obrzezanego dzięki wierze, a nieobrzezanego przez wiarę" $(3,30)^{11}$.

\section{Tłumaczenie tekstu 2,9-16}

$2{ }^{9}$ Utrapienie i ucisk spadna na każdego człowieka, który dopuszcza się zła, najpierw na Żyda, potem na Greka; ${ }^{10}$ chwała natomiast, cześć i pokój dla każdego, kto czyni dobro, najpierw dla Żyda, potem dla Greka. ${ }^{11}$ Bóg bowiem nie ma względu na osobę. ${ }^{12} \mathrm{Ci}$, którzy nie mając Prawa zgrzeszyli, bez Prawa również zgina, ci natomiast, co będac pod Prawem zgrzeszyli, przez Prawo zostana osadzeni. ${ }^{13}$ Albowiem nie ci którzy stuchają Prawa sa sprawiedliwi przed Bogiem,

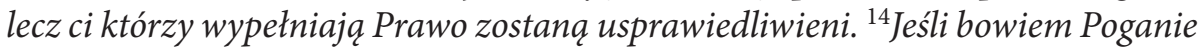
nie mając Prawa, $z$ natury czynia to co nakazuje Prawo, to chociaż go nie maja, sami dla siebie sa Prawem. ${ }^{15}$ Pokazuja oni czyn Prawa wypisanego w ich sercach, gdy ich sumienie jawi się jako świadek między jednoczesnymi myślami jednymi $i$ drugimi, tymi które oskarżaja lub bronia. ${ }^{16} \mathrm{~A}$ zostanie to ujawnione $w$ dniu w którym Bóg, przez Jezusa Chrystusa, osądzi ukryte czyny ludzkie wedlug mojej Ewangelii.

\section{Egzegeza tekstu 2,9-16}

\subsection{2,9-11: zło i dobro - kara (utrapienie, ucisk) i nagroda (chwała, cześć, pokój)}

Paweł powraca tu do treści z 2,1-8, szczególnie zaś do 2,6-8, z jednym znaczącym dodatkiem. Do wymienionych w 2,7 chwały i czci dodaje pokój, czym

11 Por. J.-N. Aletti, List do Rzymian, s. 1417. 
odwołuje się zapewne do 1,7, gdzie życzy Kościołowi rzymskiemu łaski i pokoju od Boga Ojca i Pana Jezusa Chrystusa. Wszystkie są atrybutami Boga.

Utrapienie i ucisk oznaczają kary, natomiast gniew i oburzenie określają zasady na których ma opierać się sąd, jego zakres i surowość. Zwrot na każdego człowieka (epi pasan psychēn) wyraża ideę powszechności kary. Odwołanie się do niej służy Apostołowi, z jednej strony, do wskazania bezzasadności oczekiwań Żydów iż zostaną zwolnieni od kary ze względu na swe uprzywilejowanie wynikające z Bożego wyboru i posiadanego Prawa. Z drugiej zaś strony, pomaga mu mocniej wyakcentować kryterium określające istotę Bożego sądu $(2,2)$. Będzie On dokonywał go według prawdy (kata alētheian). Paweł nie ma zatem wątpliwości, że kara dosięgnie każdego człowieka, gdyż nie sposób wyobrazić sobie, w myśl powyższej zasady, żeby człowiek niesprawiedliwy nie doznał utrapień, ucisków, cierpień zarówno na duszy jak i ciele. Zło (to kakon) zazwyczaj oznacza osoby dopuszczające się złych czynów, czyli godzących w nieskończony majestat Boga, zarówno tych dokonywanych na zewnętrz jak i tych dziejących się wewnątrz osoby ludzkiej; jawnych i ukrytych. Przedstawiona tu argumentacja opiera się na zasadach biblijnych oraz na ich judaistycznych interpretacjach znanych Apostołowi, według których Bóg będzie wynagradzał i karał według uczynków - dobrych lub złych ${ }^{12}$. Chwała jako atrybut Boga wskazuje na stan błogosławionej szczęśliwości jakiej dostąpią ci, którzy staną się uczestnikami życia wiecznego w obecności Boga. Cześć jakiej doznaje Bóg oznacza uczestnictwo w adoracji i uwielbieniu Boga w chwale nieba. Pokój natomiast opisuje stan niekończącej się i absolutnie pełnej radości, dobrobytu i obfitości wszystkich darów Bożych, którymi cieszą się uczestnicy nieba. Dodany tu przez Pawła stanowi pewnego rodzaju uzupełnienie chwały i czci w celu wyeksponowania wspaniałości, nadzwyczajności i niepowtarzalności stanu błogosławionego szczęścia człowieka przebywającego razem z Bogiem w eschatologicznym życiu wiecznym ${ }^{13}$. Stanu tego dostąpią jedynie ci, którzy czynią dobro, czyli ci którzy postępują drogą sprawiedliwości Bożej, pełniąc prawdziwie i w całej rozciągłości Jego wolę. Powtarzające się dwukrotnie odniesienia do Żydów i Greków nie pozostawiają wątpliwości, że według Apostoła to co powiedział $\mathrm{w}$ formie ogólnej w 2,1-8 odnosi się również do obu części ludzkości, a wymienione w 2,10 dary otrzymają również Poganie pełniący do-

12 Por. Pwt 28,35nn; Iz 8,22; Jr 17,9n; Ps 62(61),13; 28(27)4; Prz 24,12; Hi 34,11; Syr 16,14; Tb 4,9-11; 2 Mch 7,9; 4 Mch 7,11; PsSal 9,3-5; Abot 3,15. Mt 16,27; Ap 2,23; ApAbr 28,2; Rz 8,35; 2 Kor 6,4. Por. J.-N. Aletti, List do Rzymian, s. 1420.

13 Chwała i cześć występują często w tradycyjnych formułach liturgicznych wczesnego chrześcijaństwa (1 P 1,7; 2 P 1,17; Ap 4,9-11; 5,12n; 21,16) oraz w Septuagincie i literaturze hellenistycznej. Por. J.-N. Aletti, List do Rzymian, s. 1420. 
bre uczynki wymagane przez Prawo Mojżeszowe, choć go nie znają. Znają jednak Prawo naturalne, które również pochodzi od Boga ${ }^{14}$.

Analiza czynów ludzkich przeprowadzona w 2,7-8 służy Pawłowi do zatarcia granic między Żydami i Poganami. Wykazuje w ten sposób, że sam fakt posiadania Prawa Mojżeszowego nie daje gwarancji i nie sprawia automatycznie, że wszystkie dokonywane przez Żyda czyny są zgodne z wolą Bożą. „Dobro" czynu wynikającego z przestrzegania Prawa, który to czyn Bóg zawsze wynagradza, nie polega na tym że jest wyłącznie skutkiem zachowania Prawa, lecz jego „dobro” leży w wytrwałym trwaniu w dobrych uczynkach, czyli takich które wykraczają poza aktywność czysto ludzką i szukają jego Boskiego komponentu. Polega to na tym, że z jednej strony muszą one przyczyniać się do pomnażania oddawanej Bogu czci i chwały, z drugiej zaś, zbliżać osobę ludzką do nieśmiertelności - tj. życia wiecznego z Bogiem. Zatem, aby czyn ludzki mógł być w swej istocie "dobry” z punktu widzenia Boga, to musi on być trwale ukierunkowany na Niego samego oraz na dar nieśmiertelności człowieka. Gdy chodzi o „zło”, które zawsze podlega Boskiej karze, to według Pawła może je zawierać również dobry czyn będący skutkiem zachowania Prawa naturalnego i objawionego. Tak się dzieje, jeśli jest on dokonywany wyłącznie ze względu na egoistyczne korzyści ludzkie, czyli jest podyktowany jedynie względami ludzkimi, czyli wykluczającymi z niego komponent Boski. W pełnieniu zarówno „dobrych” jak i „złych” czynów Żydzi posiadają pewną przewagę nad Poganami gdyż cieszą się przywilejem Prawa objawionego. Jednak - jak to uzasadnia Apostoł - dla Pogan nie musi być ono przedmiotem zazdrości, ponieważ to nie w nim leży Boże kryterium definitywnie rozstrzygające o tym czy dany czyn jest „dobry” lub „zły”. Bóg bowiem nie ma względu na osobę i nie kieruje się jej statusem religijnym. Jego wybór Żydów (9-11) oraz związany z tym przywilej pierwszeństwa i wyższości $(3,1)$ nie oznacza wcale, że jakikolwiek Żyd może czuć się na tyle zadufanym w sobie samozwańczym sędzią ludzkim żeby zawłaszczyć Prawo otrzymane od Boga w celu osiągania egoistycznych, wyłącznie ludzkich (ziemskich) korzyści. Dla Pawła, jakakolwiek by nie była różnica między Żydami i Poganami, to i tak nie jest ona na tyle istotna by była w stanie wpłynąć na podstawę i istotę sądu Bożego. Bowiem Bóg sądzi czyn ludzki wyłącznie według kryterium prawdy $(2,2)$, to znaczy, patrzy i ocenia czy jest on zgodny z Jego wolą, czy też jej się sprzeciwia. Widzi On zarówno czyn zewnętrzny jak i wewnętrzny, dostrzega wewnętrzną świętość lub zło, ponieważ doskonale zna serce człowieka, a będąc bezstronnym w osądzie jest sędzią sprawiedliwym. Każdemu udziela nagrody lub kary według tego co uczynił zarów-

14 Por. C.K. Barret, The Epistle to the Romans. Black's New Testament Commentary, s. 46; R. Haldane, Exposition of the Epistle to the Romans, s. 93n. 
no czynem widzialnym jak i niedostrzegalnym dla ludzkiego oka (Jr 17,10; Prz 24,12). Te właśnie atrybuty odróżniają Go od ludzi, gdyż ci będąc skłonnymi do korupcji, czynią się niezdolnymi do bezstronności (1Sm 16,7; $\operatorname{Krn} 19,16 n)^{15}$. Bóg, gdy przywraca sprawiedliwość to nie tylko karze złych, ale przede wszystkim naprawia wyrządzone przez nich zło, niezależnie od intencji tego kto je wyrządził. Chroni słabych czyniąc im zadość, ponieważ ich prawa zostały pogwałcone ${ }^{16}$.

\subsection{2,12-15: sumienie świadkiem obecności Prawa w sercach Pogan}

Werset 2,12 pełni funkcję wprowadzenia do 2,13-15 przygotowując czytelnika do argumentacji jaka mu zostanie w nich przedstawiona ${ }^{17}$. Paweł wykazał w poprzednich wersetach, że Żydzi i Poganie są równi przed Bogiem, z jednym wszakże zastrzeżeniem. Ta jedyna nierówność między nimi $\mathrm{w}$ relacji do Boga - z punktu widzenia Żydów - polega na ich różnym statusie religijnym, a dokładnie na tym, że Żydom Bóg objawiał się w szczególny sposób w ich dziejach i dał im za pośrednictwem Mojżesza swoje Prawo, co miałoby ich postawić w bardziej uprzywilejowanej sytuacji dającej określone korzyści, a mianowicie przywilej pierwszeństwa ${ }^{18}$. W 2,12 wyjaśnia jednak, że brak owego swoistego objawienia i Prawa u Pogan nie stawia ich ani w znacznie gorszej

15 Atrybut ten czyni z Boga kogoś bardzo bliskiego każdemu człowiekowi, który nie znajduje żadnego oparcia oraz bez określonego statusu dającego konkretne przywileje i korzyści (Pwt 1,16n). Sprawiedliwość Boża nie jest równoznaczna z egalitarną neutralnością, bowiem w przeciwieństwie do niej Bóg naprawia zło i chroni słabych.

16 Prawda o Bożej bezstronności często przewija się w księgach biblijnych (1Sm 16,7; 2Krn 19,6n; Pwt 10,17; Hi 34,19; Prz 18,5; 24,23-25; 28,21; Ps 82(81),1-4; Iz 11,3; Syr 4,22.27; 35,12-18; Mdr 6,7). Również w literaturze judaistycznej jest ona wyraźnie obecna (TesHi 4,7-9; 43,13; 3Ezd 4,39; Jub 5,12-16; 21,3-5; PsSal 2,15-18; 2,32-35; 2Ba 13,8-12; 44,2-4; AntBib 20,3n; HenEt 638n). Podobnie w księgach Nowego Testamentu: w odniesieniu do Boga (Dz 10,34; 15,8n; Jk 2,1.9; 1P 1,17) i Jezusa (Mt 22,16; par. Mk 12,14; Łk 20,21); w Corpus Paulinum (Ga 2,6; Kol 3,25; Ef 6,9). Por. C.K. Barret, The Epistle to the Romans, s. 46; R. Haldane, Exposition of the Epistle to the Romans, s. 95; J.-N. Aletti, List do Rzymian, s. 1420.

17

$\mathrm{a}=$ w. 12a: ci, którzy nie mają Prawa

$\mathrm{b}=$ w. 12b: ci, którzy są $w$ Prawie

$\mathrm{A}=$ w. 13: ci, którzy mają Prawo

$\mathrm{B}=$ w. 14-15: ci, którzy nie mają Prawa

\section{Zapłata i sprawiedliwość}

zapłata negatywna - bez Prawa zapłata negatywna - według Prawa pozytywny warunek zapłaty: wypełnić Prawo pozytywny warunek zapłaty: słuchać sumienia.

Por. J.-N. Aletti, List do Rzymian, s. 1420.

18 Paweł podkreśla ten fakt powtarzając dwukrotnie frazę: najpierw ... Żyda, potem ... Greka (2,9.10). 
sytuacji ani też w bardziej korzystnym świetle przed Bogiem. Mając bowiem Prawo i kierując się nim mogliby nie popełniać grzechów stosując się do jego norm ${ }^{19}$, nie posiadając go natomiast mogliby nie popełniać grzechów o których mówi Prawo, ponieważ nie mieliby świadomości ich popełniania, gdyż taką świadomość kształtuje Prawo. Według Apostoła nie tak to jednak wygląda z punktu widzenia Boga. Wyjaśnia, że to co Poganie mieli poznać o Bogu i Jego woli, zostało im objawione przez Stwórcę w dziele stworzenia. Co więcej odczytali dane im w ten sposób objawienie naturalne poznając Go rzeczywiście na podstawie obserwacji dzieła stworzenia. Niestety nie oddali Mu jednak czci i dziękczynienia jako jedynemu prawdziwemu Bogu. Natomiast zamiast Niego uznali za bóstwa Jego stworzenia i to im oddali swoje serca zamieniając przez to chwałe niezniszczalnego Boga na podobizny i obrazy śmiertelnego człowieka, ptaków, czworonożnych zwierząt i płazów, grzesząc w ten sposób przeciwko jedynemu prawdziwemu Bogu (1,19-21). Niestety, grzeszyli również i Żydzi, chociaż objawił się im Bóg w odrębny sposób i dał im Prawo. Ostatecznie okazało się - zgodnie z przedstawioną przez Pawła logiką - że jedni i drudzy stali się równi wobec Boga $\mathrm{w}$ nieposłuszeństwie i grzechu. W przekonaniu Pawła brak szczególnego objawienia i Prawa u Pogan absolutnie ich nie usprawiedliwia przed Bogiem i nie zamyka drogi przed Jego sądem i odpłatą (1,19-32). Podobnie jak posiadanie obu darów nie usprawiedliwia i nie zwalnia od sądu i kary Żydów z powodu ich grzechów. To co mogłoby się zatem wydawać dla Żydów przywilejem i korzyścią wcale się tym nie okazało dla nich, podobnie jak i dla Pogan brak jednego i drugiego przywileju nie okazało się korzystne, albowiem nie uchroniło to ich przed grzechami i Bożym sądem z ich powodu. Ostatecznie zarówno Żydzi jak i Poganie będą sądzeni z powodu popełnionych grzechów, a nie na podstawie ich statusu religijnego (faktu otrzymania odrębnego objawienia i Prawa lub też ich braku), ponieważ nie to będzie dla Boga kryterium definitywnie rozstrzygającym o tym kto jest sprawiedliwy przed Nim a kto nim nie jest. Jedynym takim kryterium jest Jego bezstronność oraz znajomość wszystkich czynów każdego człowieka, tych widocznych i tych ukrytych, ponieważ zna on serca wszystkich. To właśnie czyni Go sędzią sprawiedliwym: bezstronność i znajomość serca ${ }^{20}$.

19 Gorsza sytuacja, ponieważ nie mając Prawa, nie mieli podpowiedzi, jak unikać grzechów.

20 Tylko Bóg zna ludzkie serce. Stąd też, aby przekonać się o winie człowieka Bóg bada jego serce, a nie postępowanie (Pwt 4,29; 6,5; 1 Sm 16,7; 1 Krl 8,39; Jr 11,20; 12,3; 17,10; 20,12; Ps 7,10; 17(16),3; 44(43),22; 139(138),23; Prz 15,11; 17,3; 21,2; 24,12). Por. C.K. Barret, The Epistle to the Romans, 46; R. Haldane, Exposition of the Epistle to the Romans, s. 95. 
Nie wystarczy samo posiadanie Prawa, ani też nawet jego znajomość. Konieczne jest jeszcze Jego przestrzeganie, ponieważ jedynie ci, którzy wypełniają Prawo zostaną usprawiedliwieni $(2,13)$. Do istoty Prawa, jego sensu i znaczenia, należy przede wszystkim jego przestrzeganie ${ }^{21}$. Prawo nie może być traktowane jak talizman obliczony na zachowanie tego co się posiada. To narzędzie sądu. Grzech dzięki niemu nie staje się mniej grzesznym, lecz przeciwnie, bardziej grzesznym gdyż popełniany jest w sferze Prawa $(7,13)$. To co nakazuje Prawo jest dobre i dlatego gdy ludzie je przestrzegają czynią się sprawiedliwymi przed Bogiem. Prawda ta jest niezwykle istotna, ponieważ stan sprawiedliwości przed Bogiem jest warunkiem niezbędnym do wydania przez Niego wyroku uniewinniającego, czyli do orzeczenia aktu usprawiedliwienia oskarżonego. Jedynie przestrzeganie Prawa stanowiło zatem - według Pawła - skuteczne zabezpieczenie korzystnego wyroku przed Bożym sądem i karą (7,12; Ga 3,21n $)^{22}$.

W 2,14 Paweł powraca do 2,12 i odpowiada na pytanie: dlaczego Poganie, którzy nie mieli możliwości kierowania się normami Prawa, a czego oczekuje Bóg, mają zginąć $(2,11)$ ? Dlaczego mają zostać ukarani jeśli nie mogli być sądzeni zgodnie z procedurą prawną? Sam przecież Apostoł uważa, że bez Prawa nie ma grzechu, że to dzięki niemu zdobywa się znajomość grzechu, że to ono ożywia grzech $(5,13 ; 7,7.9)$. Odpowiedź na tak postawione pytania brzmi, że Poganie wcale nie znajdują się poza sferą Prawa, choć rzeczywiście żyją poza sferą Prawa Mojżeszowego. Bo choć Poganie nie posiadają Prawa Mojżeszowego, to jednak $z$ natury (fysei) swej czynią to, co ono nakazuje, a to oznacza w przekonaniu Pawła - że sami dla siebie są Prawem z racji stworzenia ich przez Boga $(2,14)$. I to właśnie z tej racji Poganie są zdolni do popełniania grzechów, w konsekwencji których grozi im sąd i kara. Według Pawła zatem nie mogą czuć się samowolni w tym co czynią, lecz powinni działać zgodnie ze swą natura (fysei) stworzoną przez Boga Stwórcę, gdyż to w niej zapisał On swoje Prawo (naturalne). Fakt ten sprawia, że oni sami dla siebie są Prawem, a postępując w zgodności z samymi sobą, czyli Prawem Bożym obecnym w ich naturze, będą wypetniać dzieła Jego Prawa (ta tou nomou poiōsin) $(2,14)$. Paweł nie ma tu na myśli Mojżeszowego prawa rytualnego czy też moralnego, ponieważ stwierdza, że również i Poganie są pod grzechem; a przecież go nie znają ${ }^{23}$. Mówiąc o dziełach Prawa (ta tou nomou), ma na myśli posłuszeństwo wierze (hypakoēn pisteōs), zgodnie z tym co nakreślił w Prologu (1,5): Przez Niego otrzymaliśmy

21 Paweł jest w tym zgodny z ówczesną judaistyczną wykładnią Prawa Mojżeszowego. Por. Rz 10,5; Ga 3,10nn; Aboth III,10.

22 Por. C.K. Barret, The Epistle to the Romans, 47n; R. Haldane, Exposition of the Epistle to the Romans, s. 96.

23 Por. Rz 3,9; 3,19.23; 11,32; Ga 3,22. 
łaskę i urząd apostolski, aby ku chwale Jego imienia pozyskiwać wszystkich Pogan dla posłuszeństwa wierze. W jego przekonaniu zatem tylko posłuszeństwo wierze w Boga, ich Stwórcę i całego wszechświata, a w konsekwencji Jego Prawu, może stanowić jedyny godziwy fundament dla relacji stworzenia ze Stwórcą. Rozpoznali to Poganie, ale niestety postąpili fałszywie ponieważ nawiązali relację ze stworzeniem a nie Stwórcą. Teraz jednak powinni to posłuszeństwo ponownie rozpoznać w pełnej prawdzie objawienia Bożego w Jezusie i zaakceptować je, ponieważ stworzenie powinno nawiązać relację ze swoim prawdziwym Stwórcą ze względu na swój los w wieczności. Odczuwali oni istnienie w swej naturze tej fundamentalnej konieczności nawiązania relacji ze Stwórcą, ponieważ jej pragnienie jest obecne w całym stworzonym świecie od początku jego zaistnienia (1,19nn). Boże Prawo zostało wypisane w sercach ludzkich $(2,15)^{24}$. $\mathrm{Z}$ tej też racji, idąc za głosem serca, powinni oddać Bogu cześć $i$ dziękczynienie i w ten właśnie sposób, na tej drodze poznania stworzenia i jego Stwórcy, nawiązać z Nim właściwą relację. Taką, którą definiuje i wyznacza posłuszeństwo wierze w Niego i Jego Prawo. Jeśli człowiek rozpozna tę relację i zaakceptuje Jego wolę, będzie w stanie czynić to czego żąda od niego natura ludzka (fysei), czyli zapisane w niej, tj. w sercu, prawdziwie pochodzące od Stwórcy Prawo Prawo naturalne $(2,15)^{25}$. Apostoł nie rozwija tu myśli stoickiej, neoplatońskiej i Filona. Odwołuje się do niej tylko w takim zakresie by wykazać, że i Poganie, choć nie mieli Prawa Mojżeszowego, to jednak łamali Prawo naturalne zapisane przez Stwórcę w ich sercach ${ }^{26}$.

Relacje między człowieczeństwem, naturą i Prawem Paweł doprecyzowuje w 2,15. Reasumując wcześniejszą argumentację stwierdza, że gdy Poganie dokonują czynów wymaganych Prawem, to pokazują tym samym efekt funkcjonującego w ich sercach Prawa naturalnego zapisanego tam przez Boga Stwórcę

24 Żydzi w przeciwieństwie do Pogan otrzymali nadto szczególne objawienie Boże oraz Jego Prawo za pośrednictwem Mojżesza. Serce w Biblii symbolizuje istotę człowieka, jego osobowość którą definiują: umysł, pamięć, uczucia, myśli, pragnienia i wola. To centrum duchowego życia osoby ludzkiej i najbardziej intymne miejsce w którym spotyka się ona z Bogiem. To ośrodek świadomości dobra i zła oraz wolnej woli człowieka. Por. S. Szymik, Starotestamentowe, judaistyczne i grecko-rzymskie pojęcie sumienia, Forum Teologiczne, s. 9.

25 Paweł odwołuje się tu do myśli stoickiej, neoplatońskiej i Filona, rozpowszechnionej w świecie hellenistycznym, a za pośrednictwem Filona również w judaizmie diaspory. Współczesny mu judaizm oraz pisma rabinackie nie mówią nic o Prawie wypisanym w sercach Pogan. Jest ono wypisane w sercach Izraelitów, zgodnie z obietnicą Boga daną za pośrednictwem proroka Jeremiasza (31,33). Por. J.-N. Aletti, List do Rzymian, s. 1420.

26 Por. C.K. Barret, The Epistle to the Romans, s. 49; R. Haldane, Exposition of the Epistle to the Romans, 97; S. Szymik, Starotestamentowe, judaistyczne i grecko-rzymskie pojeccie sumienia, s. 13-15. 
w akcie stworzenia człowieka jako osoby ludzkiej. Obecne w jego sercu Prawo odciska swe znamię nie tylko w nim, lecz również i w jego umyśle, co uwidacznia się w rodzących się w nim myślach. $\mathrm{O}$ jego istnieniu i wpływie na serce i umysł zaświadcza syneidesis (sumienie) ${ }^{27}$. Paweł odwołuje się tu ponownie do terminologii i myśli stoickiej i Filona, gdzie sumienie opisywane jest jako świadek, oskarżyciel i sędzia ${ }^{28}$. W tym miejscu Paweł nazywa je świadkiem wspótświadczacym (symmartyrousēs) ${ }^{29}$. Tak przedstawione przez Apostoła znaczenie tego słowa jest zgodne z jego najwcześniejszym etymologicznym sensem, który wyrażał bardziej retrospektywne spojrzenie oskarżające i osądzające. W przekonaniu Pawła jest ono w stanie działać w charakterze świadka opowiadającego się za lub przeciw ${ }^{30}$. Nie może być przeciągane przez nikogo z zewnątrz na jedną lub drugą stronę, jak to bywa z ludzkimi świadkami. Może natomiast występować zarówno przeciwko jednej jak i drugiej stronie konfliktu myśli pojawiającego się w umyśle człowieka. Znajduje się pomiędzy jedną a drugą stroną sporu, to znaczy pomiędzy myślami broniącymi a myślami oskarżającymi $(2,15)$. To zróżnicowane działanie jest możliwe ponieważ daje ono świadectwo w bardzo ścisłej łączności z czymś czego Paweł nie wymienia tu wprost, lecz z kontekstu należy wnosić, że chodzi mu z całą pewnością o Prawo. I to właśnie z nim wspótświadczy (symmartyrei) w konkretnej sprawie, rozstrzygając powstały spór wewnętrznie sprzecznych myśli ${ }^{31}$. W przypadku Poganina nie może to być Prawo Mojżeszowe, ponieważ go nie zna. Może nim być tylko Prawo naturalne, wypisane przez Stwórcę w sercu ludzkim w akcie stworzenia

27 W myśli filozoficznej i w literaturze greckiej było rozumiane jako świadomość, (współ)wiedza, przeświadczenie, poznanie spraw, wtajemniczenie w nie, lub jako poczucie winy. W literaturze rzymskiej, szczególnie Cycerona i Seneki, odpowiednikiem greckiego syneidēsis jest łacińskie conscientia rozumiane podobnie jako współwiedza, świadomość w sensie poznania, świadomość moralna dobra i zła w osobie ludzkiej oraz zdolność osądu jej postępowania. Według Seneki conscientia to pierwotna i nieusuwalna świadomość wpisana w byt człowieka. Por. S. Szymik, Starotestamentowe, judaistyczne i grecko-rzymskie pojęcie sumienia, s. 12.15-17.

28 To świadomość moralna osądzająca postępowanie człowieka, wpisana w jego byt od początku istnienia. W tradycji biblijnej i judaistycznej taką funkcję pełni serce człowieka. Por. S. Szymik, Starotestamentowe, judaistyczne i grecko-rzymskie pojęcie sumienia, s. 15.17n.

29 Podobnie jak w 9,1 i 2 Kor 1,12. Świadomość daje świadectwo i wspótświadczy tym samym z Prawem wypisanym w sercu, które również wydaje świadectwo o dobru lub złu postępowania człowieka. Jest ono częścią wiedzy, jaką człowiek dzieli z Bogiem.

30 Paweł pozostaje tu w obrębie terminologii biblijnej, apokryficznej i Filona, gdzie sumienie jest określane mianem świadka, oskarżyciela i sędziego działań ludzkich. Por. S. Szymik, Starotestamentowe, judaistyczne i grecko-rzymskie pojęcie sumienia, s. 12.

31 Symmartyreō: dawać świadectwo wraz z kimś, świadczyć wraz z kimś, poświadczać wraz $z$ kimś. 
go jako osobę ludzką. Jest ono zatem świadkiem toczącej się wewnątrz umysłu debaty myśli inspirowanych Prawem Bożym ${ }^{32}$, stąd też myśli oskarżających lub usprawiedliwiających postępowanie człowieka przed dawcą tegoż Prawa. W przekonaniu Pawła jest więc świadkiem Bożego Prawa wypisanego w sercu i jednocześnie działającego w umyśle ludzkim, w jego myślach tam powstających, tj. w jego świadomości którą one tworzą i kształtują. Świadomości przekonanej, z jednej strony, o naturalnym Prawie Bożym obecnym w sercu i umyśle ludzkim, z drugiej zaś, odczytującej w sobie konieczność dokonywania osądu wszystkich zachowań człowieka w jego świetle i pod jego rygorem ${ }^{33}$.

W przeprowadzonej tu argumentacji ujawnia się zamiar Apostoła połączenia $\mathrm{w}$ jednej osobie ludzkiej hellenistycznego ratio z judaistycznym sercem, jej wymiaru racjonalnego (poznawczego) z wymiarem wolitywnym, oraz próba opisu sposobu ich funkcjonowania w człowieku stworzonym na obraz $i$ podobieństwo Stwórcy (Rdz 1,27). Wydaje się, że Apostoł powraca tu do samego początku biblijnej antropologii, do momentu zanim ludzkość została podzielana na Żydów i nie-Żydów, Naród Wybrany i Pogan (resztę ludzkości) ${ }^{34}$. W jego przekonaniu Prawo wypisane przez Stwórcę w sercu osoby ludzkiej oraz jej umysłowa (racjonalna) świadomość konieczności odnoszenia się do niego w osądzaniu wszystkich jej zachowań i czynów stanowi istotę człowieczeństwa arcydzieła i korony Bożego stworzenia, istotę którą zdaje się utożsamiać z tchnieniem życia danym człowiekowi przez Stwórcę w akcie stworzenia ${ }^{35}$, dzięki któremu człowiek stał się istotą żywa - osobą podobną Bogu w tym, że myśli, odczuwa, pragnie i dokonuje wyborów $(\operatorname{Rdz} 1-2)^{36}$. Sięga on samego

32 Paweł nie mówi w tym miejscu wprost o Prawie Bożym (naturalnym), ale wynika to bezpośrednio $\mathrm{z}$ kontekstu.

33 Pawłowy opis sposobu działania sumienia jest próbą oddania niejasnego greckiego zwrotu metaksy allēlon - między jednymi a drugimi. Por. C.K. Barret, The Epistle to the Romans, s. 50n; R. Haldane, Exposition of the Epistle to the Romans, s. 98n.

34 Pomaga mu to również w budowaniu jedności Kościoła złożonego z Żydów i Greków (judeo- i etno-chrześcijan).

35 Najczęściej stosowane słownictwo biblijne opisujące istotę i funkcję sumienia to: serce (lēb, lēbāb), nerki (kelājot), mądrość (bînâ, hokmâ), duch/tchnienie (rûah), dusza (nefesz). Por. S. Szymik, Starotestamentowe, judaistyczne i grecko-rzymskie pojęcie sumienia, s. 8.

36 Według Biblii człowiek od chwili stworzenia dysponuje (współ)wiedzq moralną dzieloną z Bogiem dzięki wypisanemu w sercu Prawu. Sumienie jest tego świadkiem, zatem istnieje ono w nim od samego początku, od momentu jego stworzenia. Por. B. Janowski, Der Mensch im alten Israel, s. 143-175; S. Szymik, Starotestamentowe, judaistyczne i greckorzymskie pojęcie sumienia, s. 11. 
początku stworzenia, ponieważ w kolejnym wierszu odwoła się do dnia Pana, sądu ostatecznego i eschatologicznego dopełnienia dzieła stworzenia.

\subsection{2,16: sąd Boży przez Jezusa Chrystusa na podstawie Ewangelii}

W ostatnim wersecie Apostoł zapowiada, że absolutna autentyczność przedstawionej wyżej wykładni zostanie potwierdzona w dniu sądu Bożego $(2,16)$. W jego trakcie Bóg jako sędzia sprawiedliwy osądzi absolutnie wszystkie czyny ludzkie, co podkreśla przez bezpośrednią wzmiankę o czynach ukrytych. Pozostaje tu zgodny $\mathrm{z}$ tradycją biblijną według której to dopiero one mówią pełną prawdę o człowieku przed Bogiem, prawdę o tym kim rzeczywiście jest w świetle Jego woli i sprawiedliwości ${ }^{37}$. Nadto, co niezwykle istotne w wypowiedzi Apostoła, to wskazanie, że Bóg dokona sądu nie na podstawie Prawa Mojżeszowego ani Prawa naturalnego, lecz na podstawie Ewangelii głoszonej przez Apostoła: według mojej Ewangelii (kata ton euaggelion mou). Dlaczego właśnie według niej? Ponieważ, jak to wyraził w propositio do całego Listu: jest ona bowiem moca Boża ku zbawieniu dla każdego wierzacego, najpierw dla Żyda potem dla Greka $(1,16)$. Apostoł, wieńcząc w tym wersecie argumentację całej jednostki retorycznej, wzywa w taki właśnie sposób swoich adresatów (Żydów i Greków) do wyznania wiary bądź jej umocnienia (w przypadku chrześcijan) w Jezusie Chrystusie. Żydom oświadcza, że rzeczywiście to Bóg Jahwe będzie ich sądził jak tego oczekują, jednak w taki sposób jakiego się nie spodziewają, bowiem dokona tego przez Chrystusa Jezusa (dia Christou Iēsou), to znaczy przez pryzmat dzieła zbawienia jakiego w Nim dokonał oraz na podstawie Jego Ewangelii, tej samej którą teraz właśnie im ogłasza. To samo dotyczy i Pogan nie wystarczy im już dłużej Prawo naturalne. Dlatego jedni i drudzy, powinni w całości poznać Ewangelię Jezusa, zaakceptować i zastosować się do wszystkich jej wymogów by wejść w posiadanie Chrystusowej Mocy Bożej wiodącej niezawodnie do zbawienia wiecznego, do którego zmierzali dotychczas nieskutecznie na drodze Prawa objawionego i naturalnego. I jeszcze jedna niezwykle istotna konkluzja w kwestii obecnego i przyszłego stanu serca i sumienia Żydów i Pogan, na co wskazuje treść tego wersetu. Apostoł daje tu wyraźnie, choć pośrednio, do zrozumienia, że odtąd serca Żydów i sumienia Pogan powinny być edukowane i formowane przez Jezusa Chrystusa i Jego Ewangelię, a nie jak dotąd Prawem Mojżeszowym i naturalnym, ponieważ od wydarzenia zbawczego w Chrystusie nie reprezentują już te dwie instytucje zbawczej mocy Bożej $(1,16)$. To przez wiarę w Jezusa i coraz głębsze poznawanie Jego Ewan-

37 Bóg bada serce, a nie postępowanie człowieka by przekonać się o jego winie lub sprawiedliwości (Pwt 4,29; 6,5; 1 Sm 16,7). 
gelii dokonuje się zapisywanie mocą Bożą w ich sercach i sumieniach Nowego Prawa - Prawa Ewangelii Mesjasza i Syna Bożego, dokonuje się ich obrzezanie objawioną wolą Bożą w osobie i dziele Jezusa. Od chwili wyznania wiary w Niego i poznania Jego Ewangelii ich sumienia muszą zacząć współdziałać i (współ) świadczyć z nią w kwestii moralnej oceny wszystkich czynów ludzkich. Tak właśnie musi się stać, ponieważ odtąd to jedynie ewangelicznie obrzezane, to znaczy poddane woli Bożej objawionej w Jezusie, serca i sumienia będą w stanie skutecznie zbawczo rozstrzygać wewnętrzne spory i sprzeczności dotyczące sprawiedliwego osądu czynów każdego człowieka przed obliczem Boga i Jego Syna Jezusa Chrystusa.

\section{Wnioski: obrzezanie serca i sumienia Ewangelią Jezusa}

Przeprowadzona analiza egzegetyczna jednostki 2,9-16 oraz jej kontekstu (sekcji 1,18-4,25) upoważnia do następujących konstatacji. Paweł najwyraźniej zmierza tu do ukazania usprawiedliwienia całej ludzkości jako daru łaskawej sprawiedliwości Boga, znacznie wykraczającego poza oczekiwany przez pobożnych Żydów sąd i karę. Ukazując całą ludzkość, bez wyjątku i przywileju, w tej samej negatywnej sytuacji przed Bogiem udowadnia, że usprawiedliwienie może być dostępne dla Żydów i Greków w taki sam sposób, a mianowicie tylko przez wiarę w Jezusa Chrystusa Syna Bożego; winni są bowiem jedni i drudzy. Kwestionuje on dotychczas istniejące kategorie religijne Żyda i Greka dowodząc, że prawdziwym Żydem nie jest ten kogo uważa się za Żyda, lecz może nim być również Grek obrzezany w swoim sercu przez wypisane w nim Prawo Boże (naturalne), jak również ten Żyd, który jest ukrytym Żydem - czyli z obrzezanym sercem, a nie ten obrzezany fizycznie na ciele. $Z$ punktu widzenia Boga nie ma z jednej strony takich, którzy znają Jego wolę, gdyż mają Prawo Mojżeszowe, z drugiej zaś takich, którzy go nie mają i dlatego jej nie znają. Albowiem jedni mogą ją rozpoznać w Prawie objawionym, drudzy zaś w Prawie naturalnym. Zasadniczym celem prowadzonej tu argumentacji, w związku z dokonanym dziełem usprawiedliwienia, jest doprowadzenie adresatów Listu do jedynego kryterium decydującego o tym, kto jest sprawiedliwy przed Bogiem, a kto takim nie jest, czyli nakłonienie Żyda do obrzezania serca a Greka do obrzezania sumienia, to znaczy do całkowitego poddania ich woli Bożej objawionej w Jezu$\mathrm{sie}^{38}$. W przekonaniu Apostoła Poganie dzięki sumieniu mają pewne poczucie

38 Obrzezane serce, to serce poddane Bogu, posłuszne $\mathrm{Mu}$, należące do Niego (Pwt 10,16; 30,6; Kpł 26,41; Jr 9,24n). Obrzezanego serca są ci, którzy sprawują kult w Duchu Bożym i chlubią się w Chrystusie (Flp 3,2b-3). Chrześcijanie zostali obrzezani w Chrys- 
sprawiedliwości Bożej, gdyż doświadczają działania wypisanej w ich sercach woli Bożej i w zawiązku z tym odczuwają konieczność etycznej oceny swych czynów w jej świetle ${ }^{39}$. Apostoł chce ich skłonić do wejrzenia w własne sumienia by dostrzegli kryjące się tam sprzeczności i nieobrzezanie, bowiem tym, co podoba się Bogu jest obrzezane serce Żyda i obrzezane sumienie Greka. Bóg nie spełnia swej sprawiedliwości na podstawie kategorii zewnętrznych (obrzezanie lub nieobrzezanie cielesne), lecz według uczynków oraz obrzezanego serca dla jednych i obrzezanego sumienia dla drugich. Paweł pozostaje tu najwyraźniej w sferze terminologii i idei biblijnych oraz międzytestamentalnego judaizmu palestyńskiego i hellenistycznego zakorzenionego w myśli i literaturze greckiej. Jako judeochrześcijanin wykształcony w ortodoksyjnym judaizmie i wychowany w judaizmie diaspory helleńskiej mówi o obrzezanym sercu gdy zwraca się Żydów, lecz gdy zwraca się go Greków poszerza żydowską ideę obrzezania serca o idee stoickie, neoplatońskie i Filona mówiąc o obrzezanym sumieniu (obrzezaniu umystu, myśli), ponieważ Prawo wypisane przez Stwórcę w ich sercach oddziałuje na ich ratio (umyst, myśli). Żydzi i Grecy powinni zatem dążyć do poddania się w całej swej integralności osoby ludzkiej - serca i umystu $\mathrm{Bogu}^{40}$. Jego sprawiedliwość nie polega bowiem jedynie na karaniu człowieka z powodu złych uczynków, lecz jej funkcja polega przede wszystkim na udzielaniu atrybutów Boga (bezstronności, chwały, czci i pokoju) temu kto pełni dobre dzieła ${ }^{41}$. Prawda ta stanowi dla Apostoła niewątpliwie punkt wyjścia do wezwania do dalszej edukacji i formowania serca i sumienia, do ich obrzezania, przez coraz głębsze poznawanie Ewangelii Jezusa, gdyż to ona jest aktualnnie jedyną moca Boża prowadzącą skutecznie do zbawienia każdego wierzącego w Jezusa Chrystusa Syna Bożego $(1,16)^{42}$.

Paweł chce tu najwyraźniej nadać pogańskiemu pojęciu sumienie podobny sens i funkcję jaką pełni serce $\mathrm{w}$ dobrze znanej mu tradycji biblijnej i judaistycznej. Pragnie wykazać, że tak jak dla Żyda serce stanowi kryterium rozstrzygające o tym, które jego czyny są złe, a które dobre w świetle objawionej w Prawie woli Bożej, tak dla Greka jego sumienie miało taki sam sens i pełniło identycz-

tusie, ponieważ za sprawą Ducha otrzymali nowe serce, stali się nowym stworzeniem (Kol 2,11; Ga 5,6.15).

39 Jest do doświadczenie i odczucie ograniczone, lecz rozpoznawalne dla wielu i skuteczne, co poświadczają pełniący dobre czyny.

40 W Biblii serce ludzkie to ośrodek świadomości i wolnej woli człowieka, natomiast w świecie greckim tym ośrodkiem jest ratio - rozum, umysł ludzki; tu mieści się świadomość, wiedza.

41 Por. J.-N. Aletti, List do Rzymian, s. 1421.

42 Szczególnie widoczne w wezwaniach do odnowy myśli w Rz 12,1-2; 14,15-23. 
ną funkcję w ocenie własnego postępowania w świetle Prawa naturalnego. Tak sformułowane wnioski czyni punktem wyjścia do dalszej wykładni w kwestii funkcji i znaczenia serca i sumienia. Stwierdza, że skoro wszyscy Żydzi i Grecy znaleźli się w identycznym położeniu wobec sprawiedliwości Bożej, pomimo posiadanego przez jednych Prawa objawionego, a przez drugich Prawa naturalnego, to oznacza, że jedno i drugie Prawo bezpowrotnie straciło skuteczność zbawczą. A dowodem na taki właśnie stan rzeczywistości zbawczej jest dzieło łaskawego usprawiedliwienia wszystkich za darmo, moca krwi Jezusa Chrystusa $(3,25 a)$. Żydzi i Grecy z chwilą wyznania wiary w Niego i przyjęcia w Jego Imię chrztu dostępują owej łaski usprawiedliwienia. Jednak, już jako chrześcijanie, żeby dostąpić pokoju, chwały i czci Boga w wieczności, muszą dalej swe serca i sumienia edukować i kształtować w świetle nowego Prawa - Prawa Ewangelii Jezusa. Muszą je obrzezać Ewangelią Chrystusa Syna Bożego, która stała się odtąd jedyną moca Bożą wiodąca ku zbawieniu $(1,16)$. Dowodem zaś na tak odnowiony przez Boga w osobie i dziele Jezusa stan rzeczywistości zbawczej jest to, że w dniu ostatecznym dokona On sądu nad całą ludzkością nie na podstawie Prawa, lecz przez Jezusa Chrystusa i Jego Ewangelię $(2,16)$.

\section{Bibliografia}

Aletti J-N., List do Rzymian w: Międzynarodowy Komentarz do Pisma Świętego. Komentarz katolicki i ekumeniczny na XXI wiek, W.R. Farmer (red.), tłum. M. Żurowska, Warszawa 2000, s. 1411-1455.

Barret C.K., The Epistle to the Romans. Black's New Testament Commentary, London $1991^{2}$.

Haldane R., Exposition of the Epistle to the Romans, Escondido 1999.

Janowski B., Der Mensch im alten Israel, Zeitschrift für Theologie und Kirche 102 (2005), s. 143-175.

Krawczyk R., „Prawo wpisane w sercach ludzkich“. Studium egzegetyczno-teologiczne

(Rz 2,15), Wiadomości Diecezji Siedleckiej 78, nr 2 (2009), s. 102-111.

Paciorek A., Poganie „przed Chrystusem” według Listu do Rzymian 1-2, Tarnowskie Studia Kościelne 13 (1994), s. 207-228.

Sobański R., Treść Prawa wypisana w sercach (Rz 2,15), Palestra 54, nr 1-2 (2009), s. $80-84$.

Szymik S., Starotestamentowe, judaistyczne i grecko-rzymskie pojęcie sumienia, Forum Teologiczne XV (2014), s. 7-21. 